\title{
SISTEM INFORMASI PENCATATAN SERVICE KENDARAAN TOYOTA BERBASIS WEB
}

\author{
Satria \\ Program Studi/Jurusan Sistem Informasi, STMIK Bani Saleh, \\ email: $\underline{\text { satria1905@gmail.com }}$
}

\begin{abstract}
PT. Astrido Jaya Mobilindo is one of Toyota's authorized dealers engaged in the automotive field which includes the sale of goods and services. Almost all existing systems are computer based. However, in its implementation there are still deficiencies in helping employees such as the absence of a report system in the form of graphs to facilitate the head of the workshop in analyzing the performance of the workshop and the inequality of work provided by each technician because the foreman cannot monitor the work of each technician. Therefore, the improvement of services in work must continue to be improved. The author makes a web-based vehicle service recording system with the waterfall method, where this method helps in the system development stages that are running there. Toyota's web-based service registration system has the advantage that the distribution of work to technicians is more faired and equitable with a monitoring display and can more quickly display service productivity reports because direct reports are displayed in graphical form and produce more accurate information with the smallest possible risk of error and more effective and efficient in data manipulation.
\end{abstract}

Keywords: Service, Vehicle, Monitoring, Waterfall, Web.

\begin{abstract}
ABSTRAK
PT. Astrido Jaya Mobilindo merupakan salah satu dealer resmi Toyota yang bergerak dalam bidang otomotif yang meliputi penjualan barang dan jasa. Hampir semua sistem yang ada sudah berbasis komputer. Namun, di dalam implementasinya masih ditemukan kekurangan dalam membantu para pegawai seperti contoh tidak adanya suatu sistem laporan yang berupa grafik untuk memudahkan kepala bengkel dalam menganalisa kinerja bengkel dan ketidak merataan pekerjaan yang diberikan oleh setiap teknisi karena foreman tidak bisa memonitor kerja setiap teknisi. Oleh karena itu peningkatan pelayanan dalam bekerja harus terus ditingkatkan. Sehingga penulis membuat sistem pencatatan service kendaraan berbasis web dengan metode waterfall, dimana metode ini membantu dalam tahapan pengembangan sistem yang sedang berjalan disana. Sistem pencatatan service toyota berbasis web ini memiliki keunggulan dimana pendistribusian pekerjaan kepada teknisi menjadi lebih adil dan merata dengan adanya tampilan monitoring serta dapat lebih cepat menampilkan laporan produktifitas service karena laporan langsung ditampilkan dalam bentuk grafik dan menghasilkan informasi yang lebih akurat dengan resiko kesalahan sekecil mungkin serta lebih efektif dan efisien dalam manipulasi data.
\end{abstract}

Kata kunci: Service, Kendaraan, Monitoring, Waterfall, Web. 


\section{PENDAHULUAN}

\subsection{Latar Belakang Masalah}

PT. Astrido Jaya Mobilindo merupakan perusahaan yang bergerak di bidang otomotif dan menerima permintaan servis dari konsumen. Hampir semua sistem yang ada sudah berbasis komputer. Namun, ada beberapa di dalam implementasinya masih ditemukan kekurangan dalam membantu para pegawai yang bekerja pada perusahaan tersebut seperti contoh tidak adanya suatu sistem laporan yang berupa grafik untuk memudahkan kepala bengkel atau pimpinan dalam menganalisa produktifitas teknisi maupun unit entry servis yang terjadi sehingga pimpinan harus menghitung sendiri jumlah produktifitas yang terjadi di perusahaan tersebut dan menggambarkannya kedalam bentuk grafik pada sebuah papan yang terdapat diruangannya sehingga membutuhkan waktu lebih lama, pada contoh lainnya ketidak merataan pekerjaan yang diberikan oleh setiap teknisi karena foreman tidak bisa memonitor kerja setiap teknisi apakah teknisi tersebut sedang dalam pekerjaan atau tidak dan jumlah unit entry yang telah dikerjakan teknisi karena tidak adanya menu yang dapat menunjukan hal tersebut.

Dalam menghadapi persoalan di atas, maka dibuatkan suatu sistem informasi administrasi pada PT. Akita Jaya Mobilindo. Sistem tersebut mampu untuk mengolah data transaksi menjadi informasi yang bermanfaat, serta dapat mempermudah dalam menganalisa pekerjaan yang sedang berlangsung pada perusahaan tersebut. Sehingga diharapkan sistem ini dapat memberikan konstribusi yang memadai dan bermanfaat untuk kelancaran kinerja PT. Akita Jaya Mobilindo.

\subsection{Tujuan Penelitian}

Tujuan dari pembuatan sistem informasi administrasi service kendaraan Toyota adalah:

a. Membuat sistem informasi berbasis web yang memudahkan dalam membaca produktifitas bengkel yang berupa laporan grafik

b. Untuk memudahkan tugas foreman ketika akan mendistribusikan pekerjaan kepada teknisi

c. Membuat tampilan web yang lebih terlihat berwarna sehingga membuat petugas menjadi lebih tertarik dalam melakukan aktifitas pekerjaannya

\section{METODOLOGI PENELITIAN}

\subsection{Metode Waterfall}

Pengembangan sistem didefinisikan sebagai aktivitas untuk menghasilkan sistem informasi berbasis komputer untuk menyelesaikan persoalan (problem) organisasi atau memanfaatkan kesempatan (opportunities) yang timbul (Prof. Dr. Jogiyanto HM, 2010). Model air terjun (waterfall) Biasa juga disebut siklus hidup perangkat lunak. Mengambil kegiatan dasar seperti spesifikasi, pengembangan, validasi, dan evolusi dan merepresentasikannya sebagai fase-fase proses yang berbeda seperti spesifikasi persyaratan, perancangan perangkat lunak, implementasi, pengujian dan seterusnya (Feri Hari Utami dan Asnawati, 2015)

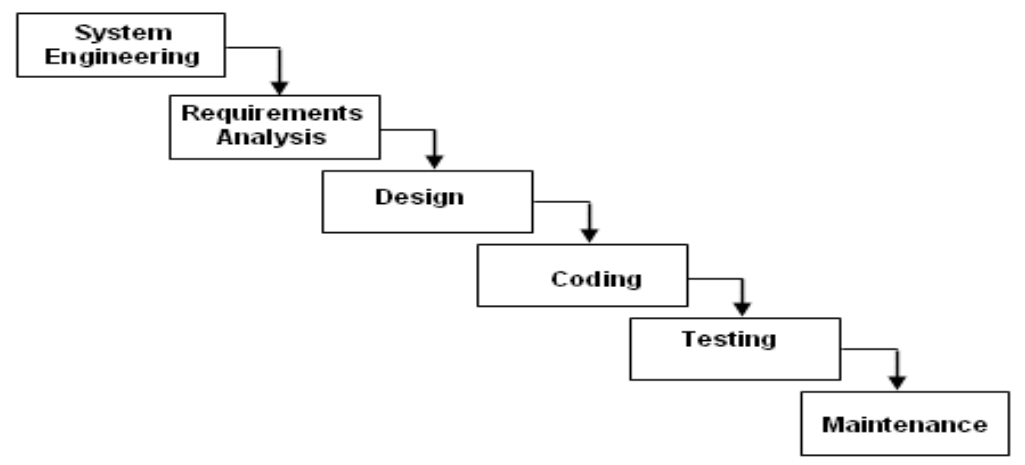

Gambar 1. Metode Waterfall 
Keterangan Menurut gambar diatas alur dari model waterfall sebagai berikut:

a. System Enginering (Rekayasa perangkat lunak), pada tahap awal dalam proses perancangan aplikasi ini yaitu melakukan pengumpulan data dan penetapan kebutuhan semua elemen sistem.

b. Requirements analysis, melakukan analisis terhadap permasalahan yang dihadapi dalam pendataan keluarga tidak mampu dan menetapkan kebutuhan perangkat lunak, fungsi performsi dan interfacing.

c. Design, pada tahap ini yaitu tahap pembuatan desain proses bisnis dan desain pemrograman untuk data-data yang telah didapatkan. Tool yang akan digunakan dalam pemodelan sistem adalah UML (Unified Modeling Language) yaitu, Use Case, Activity Diagram, Class Diagram dan Diagram Sequence, yang menggambarkan jalannya sistem yang akan dirancang. Desain interface sistem meliputi perancangan format menu dan perancangan desain interface yang akan digunakan sebagai fasilitas dialog antar sistem dan user. Serta membuat suatu penyelesaian kasus berdasarkan metode Simple Additive Weighting (SAW).

d. Coding (Implementasi), pengkodean yang mengimplementasikan hasil desain ke dalam kode atau bahasa yang dimengerti oleh mesin komputer dengan menggunakan bahasa pemprograman tertentu. Dalam sistem ini desain yang telah dibuat dikodekan dengan menggunakan bahasa pemrograman PHP (Personal Home Page) dan Database MySQL.

e. Testing (pengujian), kegiatan untuk melakukan pengetesan program yang sudah dibuat apakah sudah benar atau belum. Pada tahapan ini dilakukan pengujian pada sistem yang dibuat, pengujian sistem yang dilakukan menggunakan Black box test. Yakni dilakukan dengan mengamati output dari berbagai input jika output yang dihasilkan sesuai dengan rancangan untuk variasi data, maka sistem yang dibuat dinyatakan baik.

f. Maintenance (perawatan), menangani perangkat lunak yang sudah selesai supaya dapat berjalan lancar dan terhindar dari gangguan gangguan yang dapat menyebabkan kerusakan

\subsection{Pengertian Pencatatan}

Pencatatan data adalah proses memasukkan data ke dalam media sistem pencatatan data. Jika media sistem pencatatan data tersebut berupa buku, pencatatan data dilakukan dengan menulis pada lembar-lembar buku. Jika sistem pencatatan data berupa perangkat komputer, pencatatan dilakukan dengan mengetik melalui keyboard, penggunaan pointer mouse, alat scanner (pembaca gambar), atau kamera video. Yang termasuk dalam pencatatan data adalah aktivitas penulisan ke buku atau kertas, pemasukan data ke dalam komputer (Witarto, 2008).

\subsection{Definisi Service}

Terdapat tiga kata yang bisa mengacu pada istilah service, yakni jasa, layanan, dan servis. Sebagai jasa, service umumnya mencerminkan produk tidak berwujud fisik (intangible) atau sektor industri spesifik, seperti pendidikan, kesehatan, telekomunikasi, transportasi, asuransi, perbankan, perhotelan, kontruksi dan lainnya. Sebagai layanan, istilah servis menyiratkan segala sesuatu yang dilakukan pihak tertentu (individu maupun kelompok) kepada pihak lain (individu maupun kelompok). Salah satu contohnya adalah layanan pelanggan (customer service). Sedangkan kata servis lebih mengacu pada konteks reparasi, misalnya servis sepeda motor atau peralatan elektronik (Arief, 2007).

\subsection{Definisi Kendaraan Bermotor}

Kendaraan adalah suatu sarana angkut di jalan yang terdiri atas kendaraan bermotor dan kendaraan tidak bermotor. Kendaraan bermotor adalah setiap kendaraan yang digerakkan oleh peralatan mekanik berupa mesin selain kendaraan yang berjalan di atas rel, terdiri dari kendaraan bermotor perseorangan dan kendaraan bermotor umum. Kendaraan tidak bermotor adalah kendaraan yang digerakkan oleh tenaga orang atau hewan (UU RI No. 22 Tahun 2009). 


\subsection{Definisi Monitoring}

a. Monitoring adalah aktifitas yang ditujukan untuk memberikan informasi tentang sebab dan akibat dari suatu kebijakan yang sedang dilaksanakan.

b. Monitoring dilakukan ketika sebuah kebijakan sedang diimplementasikan.

c. Monitoring diperlukan agar kesalahan awal dapat segera diketahui dan dapat dilakukan tindakan perbaikan, sehingga mengurangi risiko yang lebih besar.

\section{HASIL DAN ANALISA}

\subsection{Analisa Sistem yang Berjalan}

Walaupun sistem yang sedang berjalan pada PT. Astrido Jaya Mobilindo ini terlihat sudah kompleks tetapi dalam pengaplikasiannya dilapangan masih memiliki beberapa kekurangan dan kendala diantaranya dalam hal pendistribusian pekerjaan yang dilakukan oleh foreman kepada teknisi dimana ketidakmerataan pekerjaan yang diterima oleh setiap teknisi terjadi seperti teknisi yang diberikan pekerjaan terus menerus oleh foreman padahal teknisi yang lainnya hanya mengerjakan lebih sedikit mobil dibandingkan dengan teknisi tersebut bahkan foreman memberikan pekerjaan kepada teknisi yang pada saat itu masih dalam pekerjaan mengerjakan mobil service yang lainnya padahal pada saat itu ada teknisi yang sedang standby menunggu pekerjaan, lalu laporan produktifitas teknisi maupun produktifitas servis kendaraan yang belum menggunakan grafik sehingga akan sulit dan membutuhkan waktu bagi petugas maupun kepala bengkel dalam mengetahui atau menganalisa kegiatan servis yang terjadi pada perusahaan tersebut karena petugas atau kepala bengkel harus terlebih dahulu melihat melalui data yang tersimpan dan secara manual menghitung jumlah produktifitas aktifitas servis kendaraan yang terjadi sehingga hal tersebut bisa menimbulkan masalah apabila ada kesalahan ataupun ada yang terlewat ketika melakukan perhitungan, ditambah apabila ada suatu data yang kurang valid sehingga menambah waktu dalam melakukan proses perhitungan.

\subsubsection{Sistem yang diusulkan pada PT. Astrido Jaya Mobilindo}

Analisis dari sistem yang berjalan, penulis mengusulkan suatu rancangan Aplikasi Sistem Informasi Pencatatan Servis Kendaraan Pada PT. Astrido Jaya Mobilindo, dengan bahasa pemrograman $P H P$ dan dengan database MySQL. Sistem yang penulis usulkan adalah sistem yang dapat digunakan langsung oleh para petugas dan mempermudah foreman dalam melakukan pendistribusian pekerjaan karena sebelumnya foreman bisa memonitor teknisi yang sedang standby atau yang sedang bekerja dan juga mempermudah pimpinan dalam melihat hasil laporan yang ditampilkan berupa grafik. 


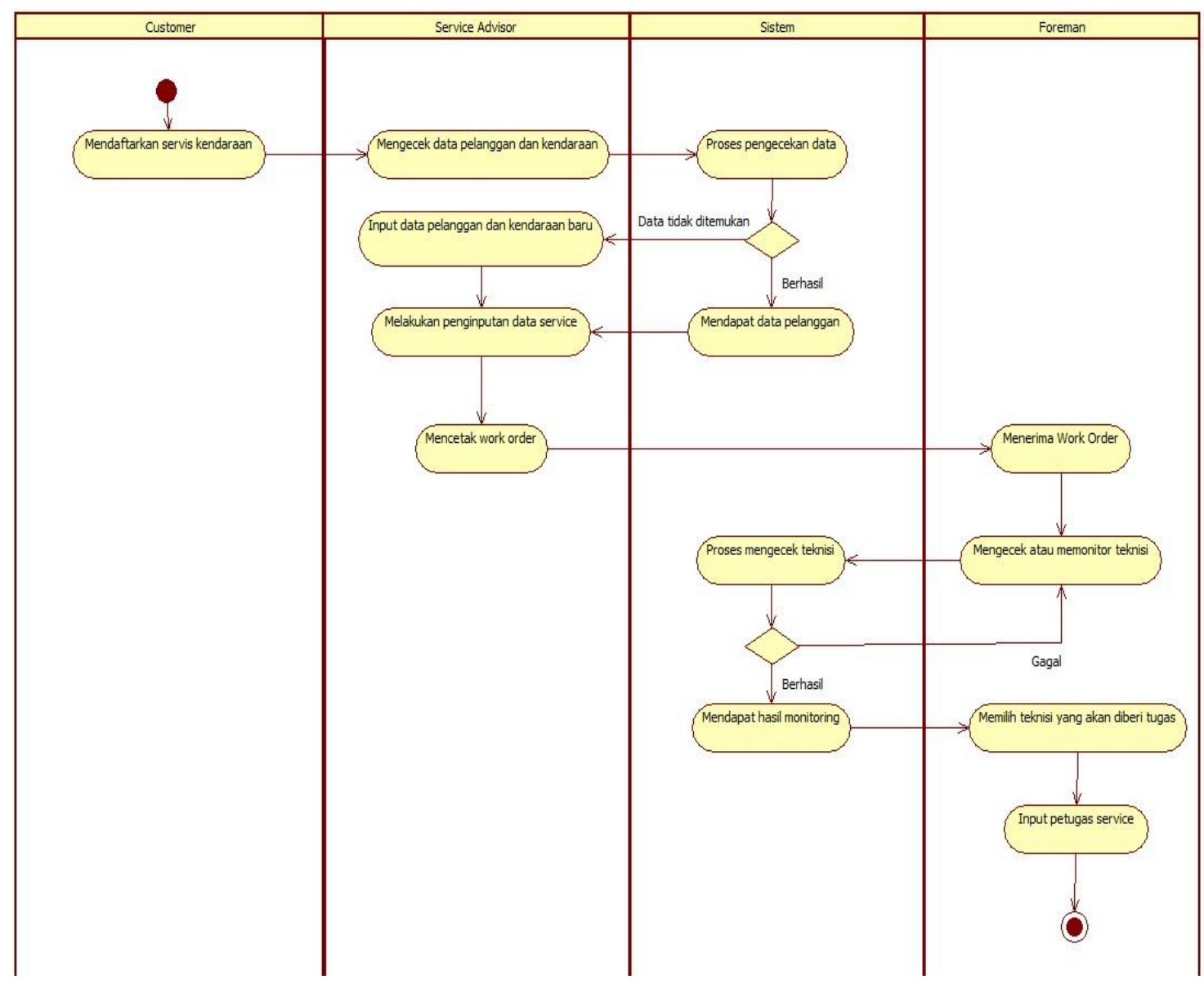

Gambar 2. Sistem yang diusulkan

\subsubsection{Kelebihan Sistem yang diusulkan}

Kelebihan dari system yang diusulkan antara lain sebagai berikut:

a. Mempermudah foreman dalam mendistribusikan pekerjaan kepada teknisi karena foreman dapat memonitor status kerja teknisi sehingga tidak lagi terjadi ketidakmerataan dalam mendistribusikan pekerjaan

b. Memberikan kemudahan dan kenyaman kepada karyawan dan petugas dalam melaksanakan aktifitas pekerjaannya dan menampilkan hasil laporan aktifitas servis yang dipilih berdasarkan tanggal.

c. Mengurangi kesalahan dalam perhitungan laporan pendapatan karena perhitungan dilakukan oleh sistem.

\subsection{Use Case Diagram}

Bagian ini akan digambarkan aktivitas aktor dengan sistem, sehingga alur aktivitas aktor dan sistem dapat dilihat dengan jelas dengan use case diagram (Gambar 3.), pada tahapan ini bertujuan untuk menentukan siapa yang menjadi pengguna dalam masing-masing menu yang akan digunakan, yang nantinya akan berinteraksi dengan sistem dan proses-proses apa saja kegiatan yang dilakukan oleh aktor terhadap sistem antara lain sebagai berikut:

1. Use case input data pelanggan

Input data pelanggan adalah suatu proses dimana service advisor melakukan penginputan terhadap data pelanggan beserta data kendaraan pelanggan tersebut yang akan melakukan service 


\section{Use case input workorder}

Input workorder adalah suatu proses dimana service advisor menginput workorder yang nantinya akan dijadikan pedoman oleh teknisi dalam melakukan pekerjaan yang akan dikerjakan terhadap kendaraan pelanggan. Didalam workorder ini juga terdapat tanggal dan jam selesai service, teknisi harus menyelesaikan pekerjaan mereka tidak boleh lewat dari waktu yang telah dibuat di dalam workorder tersebut.

3. Use case input petugas service

Input petugas service merupakan suatu proses yang dapat digunakan oleh foreman untuk menginput nama foreman dan nama teknisi yang bertugas mengerjakan pekerjaan yang terdapat didalam workorder dan bertanggung jawab penuh atas perkerjaan yang dikerjakannya.

4. Use case input pembayaran

Input pembayaran merupakan suatu proses dimana kasir menginput data pembayaran service dan memilih diskon yang sesuai sebelum memberitahukan total biaya yang harus dibayar oleh pelanggan

5. Laporan

Laporan adalah sekumpulan data yang telah di input oleh petugas yang hasilnya berupa grafik dimana nantinya laporan tersebut akan dilihat oleh pimpinan untuk menganalisa langkah selanjutnya untuk kemajuan perusahan. Selain laporan berupa grafik, pada laporan juga terdapat tampilan laporan tentang pendapatan bengkel beserta total pendapatan yang didapat dalam sehari.

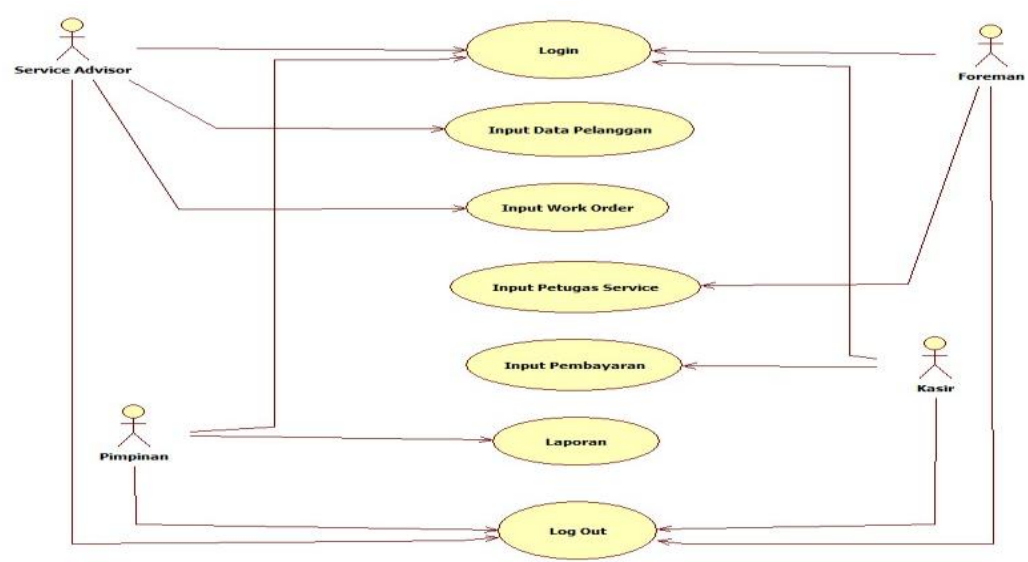

Gambar 3. Use Case diagram aplikasi pencatatan servis

\subsection{Implementasi Sistem}

Tahapan ini akan menjelaskan cara pengoperasian aplikasi pencatatan service kendaraan. Adapun penjelasan lebih lanjut sebagai berikut :

\section{Form Login}

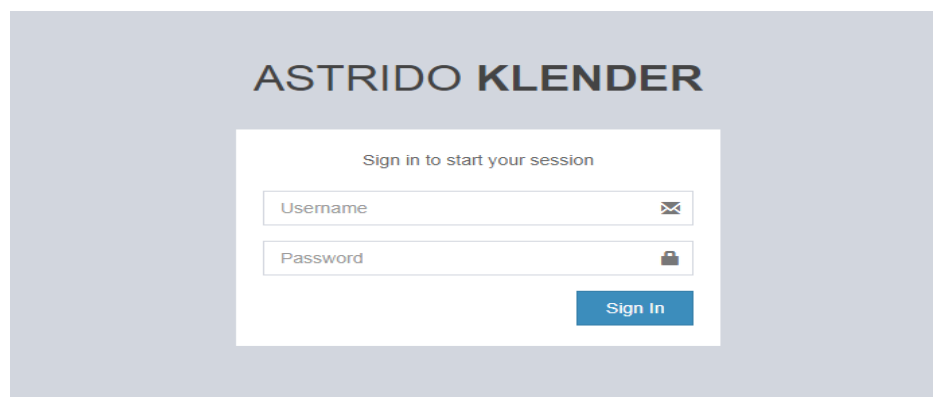

Gambar 4. Menu Login 


\section{Tampilan Dashboard}

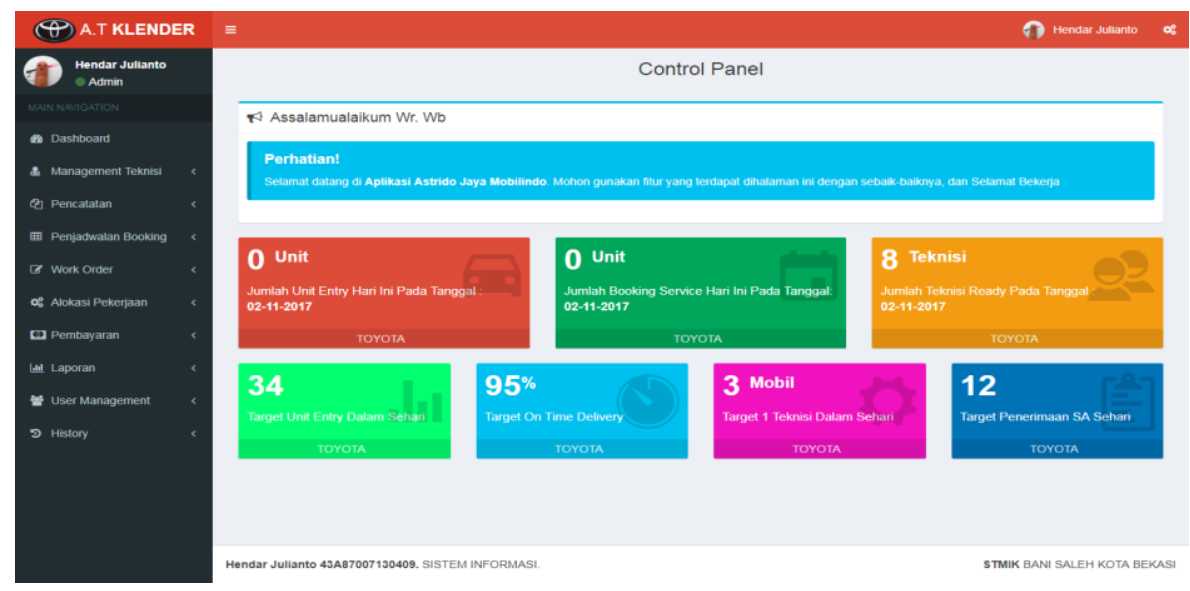

Gambar 5. Tampilan Dashboard

Pencatatan

a. Data Pelanggan

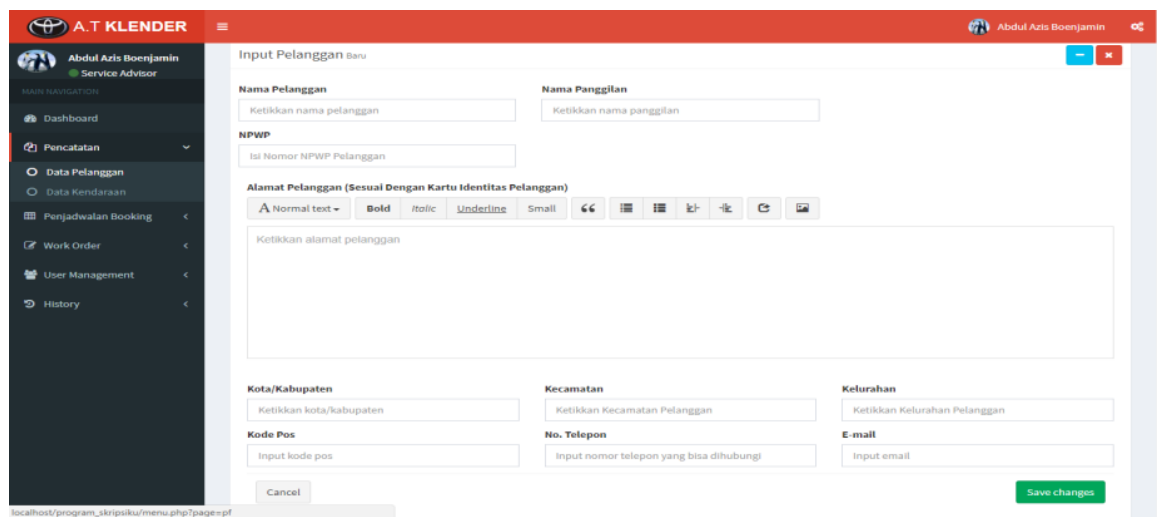

Gambar 6. Input Data Pelanggan

b. Data Kendaraan

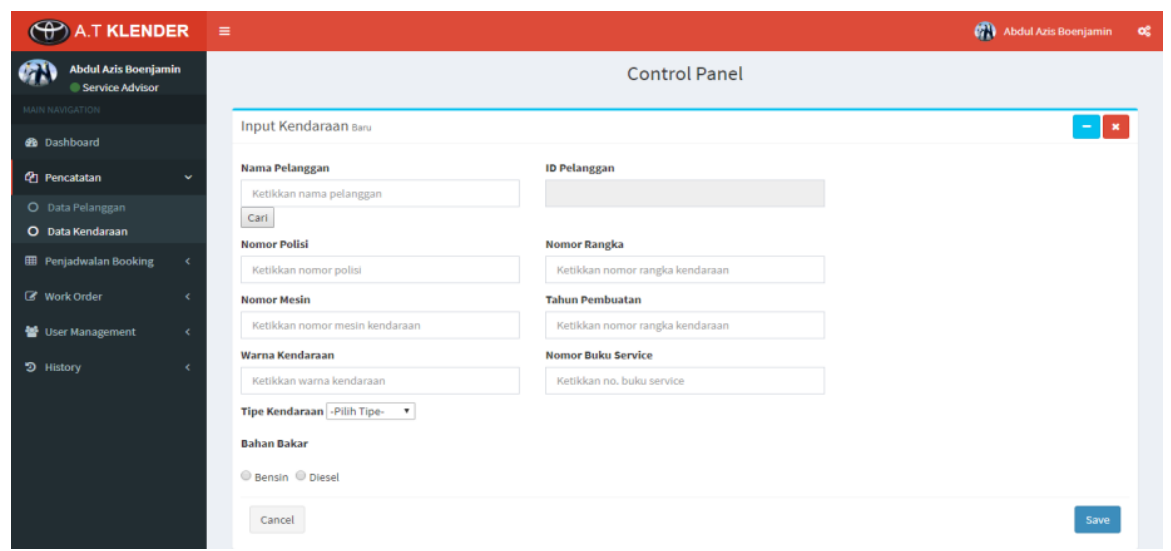

Gambar 7. Input Data Kendaraan 


\section{Work Order}

a. Pencatatan SPP/WO (Service Advisor)

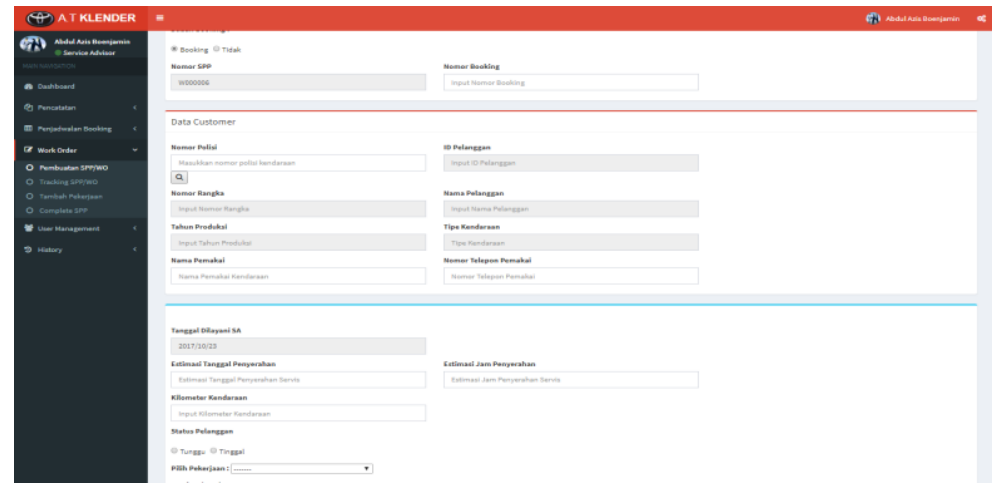

Gambar 8. Pencatatan SPP/WO

b. Tracking SPP/WO

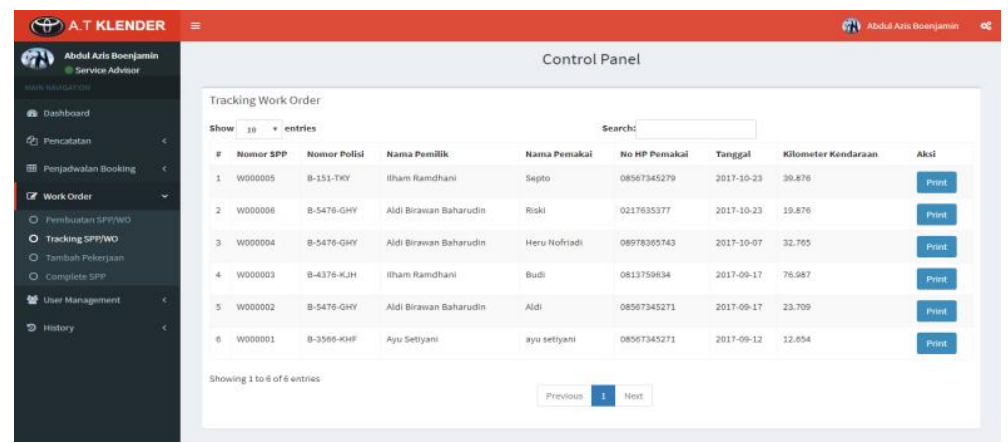

Gambar 9. Tracking SPP/WO

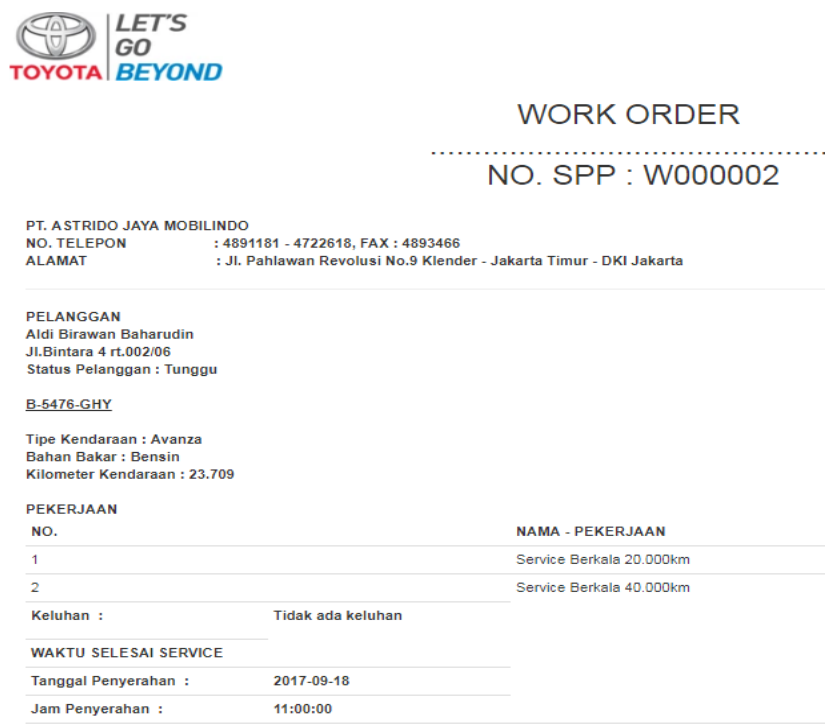




\section{Pembayaran}

a. Input Pembayaran

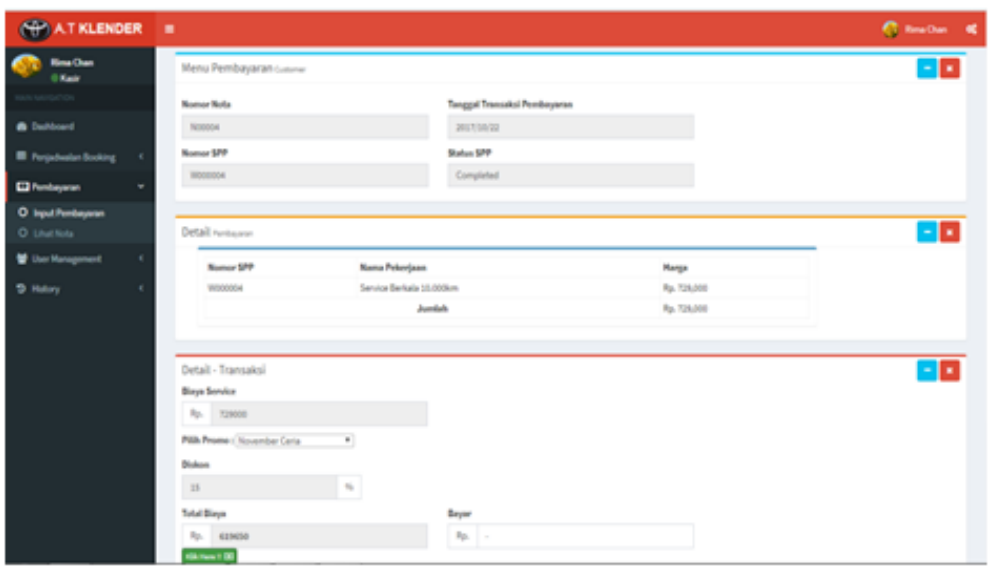

Gambar 11. Input Pembayaran

b. Lihat Nota

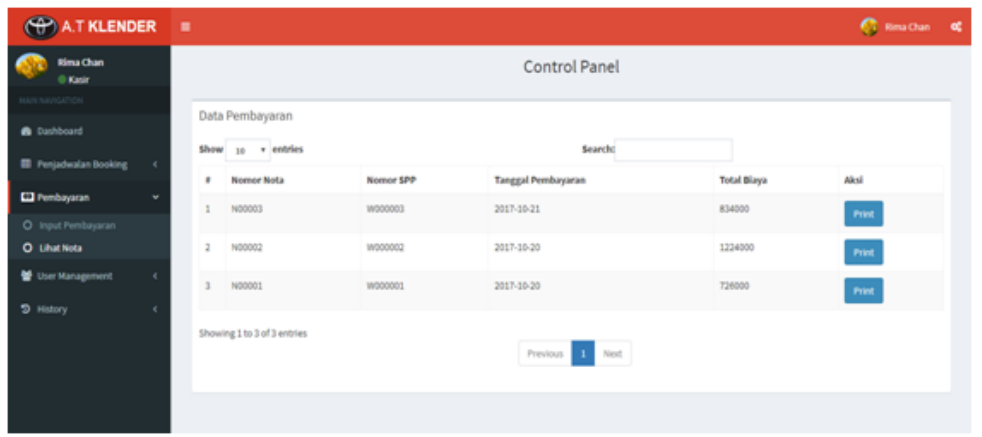

Gambar 12. Lihat Nota

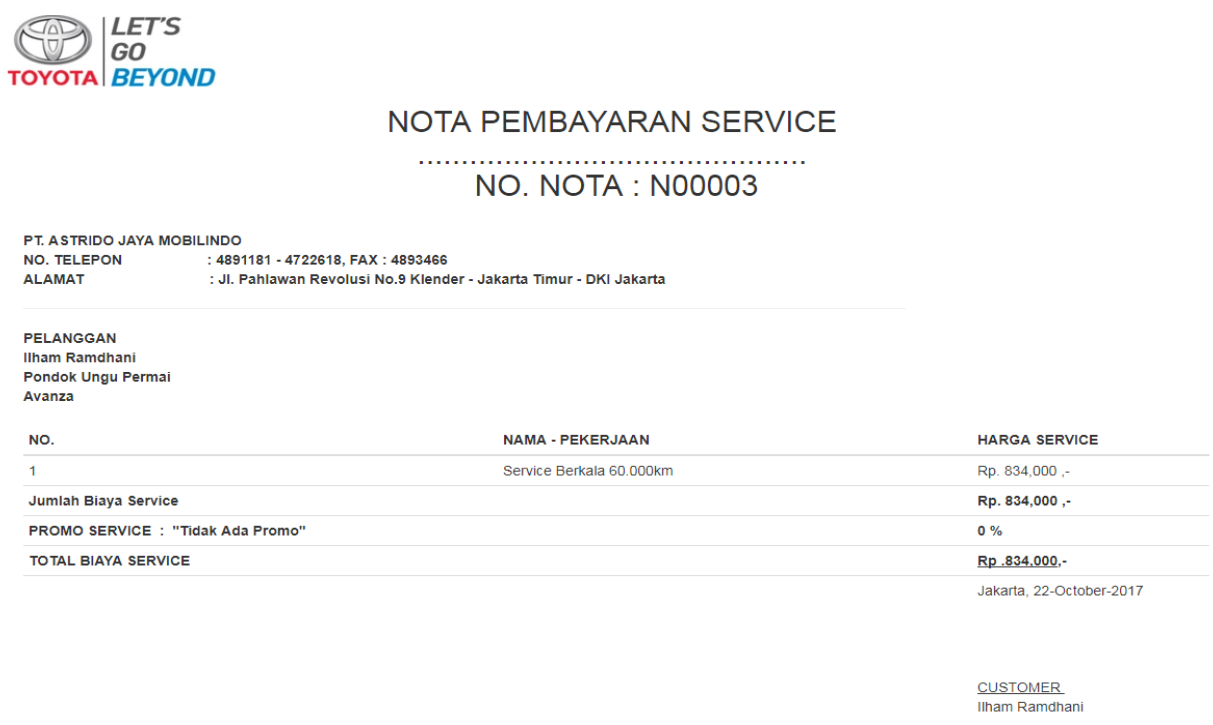

Gambar 13. Print Nota 


\section{Laporan}

a. Grafik Bengkel

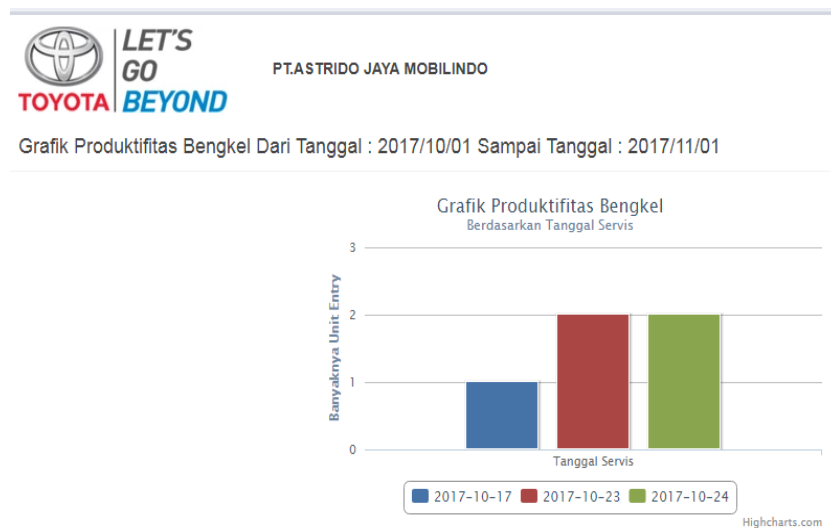

Gambar 14. Tampil Laporan

b. Laporan Pendapatan

\begin{tabular}{|c|c|c|c|c|}
\hline \multicolumn{2}{|c|}{\begin{tabular}{r|l} 
LET'S \\
TOYOTA
\end{tabular}} & \multicolumn{2}{|c|}{ PT.ASTRIDO JAYA MOBILINDO } & \\
\hline \multicolumn{5}{|c|}{ Laporan Pendapatan P. Astrico Jaya Mcoiñnso } \\
\hline \# Nomor Nota & Nomor SPP & Tanggal Pembayaran & Diskon (\%) & Total Biaya (Rp.) \\
\hline 1 No0005 & wo00005 & 2017-10-23 & $15 \%$ & Rp. $2,016,200,-$ \\
\hline 2 No0004 & wo00004 & 2017-10-23 & $15 \%$ & Rp. 619,650 ,- \\
\hline \multicolumn{4}{|c|}{ Total Pendapatan Pada Tanggal : 2017/10/23 } & Rp. $2,635,850$,- \\
\hline
\end{tabular}

Gambar 15. Print Laporan

\section{KESIMPULAN DAN SARAN}

\subsection{Kesimpulan}

1. Dengan adanya Aplikasi pencatatan service kendaraan ini menjadi alat bantu bagi pelayanan pelanggan PT. Astrido Jaya Mobilindo karena mempermudah pekerjaan petugas, Kepala Bengkel atau pimpinan tidak perlu repot lagi untuk membuat graik kedalam papan karena grafik dapat dimunculkan melalui aplikasi.

2. Dengan adanya aplikasi ini pendistribusian pekerjaan kepada teknisi menjadi adil dan sama rata karena foreman bisa melihat status teknisi terlebih dahulu sebelum memberikan pekerjaan.

\subsection{Saran}

1. Sebaiknya tampilan pada aplikasi dibuat lebih lengkap dan lebih menarik lagi sehingga petugas lebih nyaman pada saat penggunaan aplikasi tersebut.

2. Diharapkan untuk pengembangan pada sistem selanjutnya pencatatan service kendaraan ditambah menu sparepart untuk dapat mengelola part untuk service kendaraan 


\section{Daftar Pustaka}

\section{- Jurnal}

1. Christine Dewi, dan Kumala Nindya Pramono. (2015). Pembuatan Aplikasi Pencatatan Servis Mobil di PT. Armada International Motor Berbasis Android. ISSN: 2301 - 4156

2. Yohannes Yahya Welim, T.W. Wisjhnuadji, dan Rasip Firmansyah. (2015). Sistem Informasi Service Kendaraan Pada Bengkel KMFP. ISSN: 2252 - 4983

\section{- Buku}

1. Jogiyanto, (2010). Analisis dan Desain Sistem Informasi, Edisi IV, Yogyakarta: Penerbit Andi Offset

2. Witarto. (2008). Memahami Pengolahan Data. Jakarta: Penerbit Bumi Aksara.

3. Arief. (2007). Pemasaran Jasa \& Kualitas Pelayanan. Malang: Penerbit Bayumedia Publishing.

4. Undang-Undang No 22 Tahun 2009. Tentang Lalu Lintas dan Angkutan Jalan. Yogyakarta: Penerbit Pustaka Yustisia.

\section{- INTERNET}

1. http://setkab.go.id/pengertian-monitoring-dan-evaluasi-kebijakan-pemerintah 